\title{
INFLUENCE OF SOCIO-ECONOMIC FACTORS ON LAND USE AND VEGETATION COVER CHANGES IN AND AROUND KAGOMA FOREST RESERVE IN TANZANIA *NZUNDA, N.G., ${ }^{1}$ MUNISHI, P.K.T., ${ }^{1}$ SOKA, G.E. ${ }^{2}$ and MONJARE, J.F. ${ }^{3}$ \\ http://dx.doi.org/10.4314/ejesm.v6i5.5
}

Received 1st April 2013; accepted 26th July 2013

\begin{abstract}
The Miombo woodland ecosystem has been and continues to face conservation threats. We assessed the socio-economic drivers of land use and vegetation cover changes and the extent of land use/cover change in and around Kagoma Forest Reserve (KFR), Tanzania. Household survey, field observations and focus group discussions were used to obtain socio-economic data that influence land use and vegetation cover changes and logistic regression model was used to establish the relationship between socio-economic drivers and land cover change. Remote sensing and GIS techniques were used to analyze land use and vegetation cover changes over the past 23 years. Landsat imagery of 1988, 1999 and 2010 were used in this study. The perceived drivers for the changes include; overgrazing, demand for forest products, shifting cultivation, agricultural expansion, increasing crop prices and lack of land tenure. It was revealed that there has been significant land use and vegetation cover transformation from one class to another. In the period of 12 years (1988-1999) woodland, cultivated land and settlements increased by 5.8\%, 5.9\% and 0.52\% respectively, while forests decreased by 5.64\%. During 1999-2010 period woodland decreased by $22.97 \%$ and forest by $2.5 \%$, while cultivated land increased by $6.07 \%$ and settlements by $9.14 \%$. Enforcement of different laws and regulations relating to natural resources and land use planning to improve land tenure and resource use in villages bordering the forest can substantially reduce the problem of land degradation.
\end{abstract}

Key words: Land use, vegetation, cover changes, Kagoma Forest Reserve, Tanzania

\section{Introduction}

Expansion of cultivation in many parts of the world has changed land cover to more agroecosystems and less cover of natural vegetation (Lyaruu, 2002; Tiffen, 2003). These changes are fuelled by a growing demand for agricultural products that are important for improving food security and generate income, not only for the rural poor but also for the large-scale investors in commercial farming sector. Historically, humans have increased agricultural outputs mainly by bringing more land into production (Lambin et al., 2003). Natural vegetation cover has given way not only to cropland but also to native or planted pasture (Lambin et al., 2003).

During the last few decades, the area under cultivation has more than doubled in East Africa (Olson et al., 2004). Land scarcity in the highlands of East Africa caused farmers to intensify their land use because there was little land available for extension of their farms (Olson et al., 2004). Globally, concerns about the changes in land use/cover emerged due to realization that land surface processes influence

\footnotetext{
${ }^{1}$ Department of Forest Biology, Sokoine University of Agriculture, P.O. Box 3000, Morogoro, Tanzania

${ }^{2}$ Department of Wildlife Management, Sokoine University of

Agriculture, P.O. Box 3073, Morogoro, Tanzania

${ }^{3}$ Geo-Network Limited, P.O. Box 38037, Dar es Salaam, Tanzania

*Corresponding author.nanjivan@gmail.com
}

climate and that change in these processes impact on ecosystem goods and services (Lambin et al., 2003). The impacts that have been of primary concern, are the negative effects of land use change on biological diversity, soil degradation and the ability of biological systems to support human needs. Crop yields have declined, forcing people to cultivate more land to meet their needs (Kaihura and Stocking, 2003). Grazing areas have become less productive resulting from over stocking of livestock.

Anthropogenic alterations of the natural landscape through urbanization, agriculture and forestry have been continuous and increasing process for the past millennium (Vanacker, 2002). This has caused significant and adverse effects on physical and ecological process (Briassoulis, 2002), on soil and water (Munishi et al., 2006) on local and global climate and on biodiversity (Turner et al., 1994). A study by Meyer and Turner (1996) showed that land use both deliberately and inadivertly alters land cover such as vegetation by changing it into different state like building materials, medicinal, wood and fuel, hence deforestation. Recently, efforts have been made to quantify the nature 
and extent of land use/land cover changes including vegetation at global scale (e.g. Zhou et al., 2008; Dewan and Yamaguchi, 2009). Richards (1990) estimated that, over the last 300 years, the total global area of forest and woodland diminished by $19 \%$, while grasslands increased by $46.6 \%$. Despite the recognition on the magnitude and impact of global changes in land use and land cover, there have been relatively few comprehensive studies on land use changes and their impacts (Strategic Plan for the climatic change Science programme, 2003). Misana et al. (2003) reported a significant expansion of cultivation in Kilimanjaro region, as well as other north-western regions.

Despite the studies conducted in the northwestern Tanzania, little is known about the factors influencing land use and vegetation cover change in and around KFR and other forests in the world. It is widely acknowledged that increased population as a result of refugees' influx including local population increase have had impact on forest resources in the study area. While that has been said, no quantifications have been done and it is not explicitly clear whether population increase is the only cause for the changes. This paper presents an assessment the socio-economic factors influencing land use and vegetation cover change in and around KFR from 1988 to 2010 .

\section{Materials and Methods \\ Study Area}

KFR is found in the north-western Tanzania (figure 1) and lies within longitudes $1^{\circ} 29^{\prime} 49 " \mathrm{~S}$ $1^{\circ} 39^{\prime} 18^{\prime \prime S}$ and latitudes $31^{\circ} 18^{\prime} 27^{\prime \prime E}$ $31^{\circ} 19^{\prime} 20^{\prime \prime} \mathrm{E}$. The woodland covers an area of $16,697.92$ ha and is at about $1245 \mathrm{~m}$ above sea level. Soil types vary according to location, and the common ones were described by Touber and Kanani (1994). Rainfall is very much influenced by topography and the presence of Lake Victoria. A rather steep gradient in total annual rainfall is observed from $2100 \mathrm{~mm}$ along the coast to less than $700 \mathrm{~mm}$ towards the interior (Touber and Kanani, 1994). The daily temperatures are relatively low and fluctuate between $15^{\circ} \mathrm{C}$ and $28^{\circ} \mathrm{C}$, with an average of $20^{\circ} \mathrm{C}$ (Hofer et al., 2004). KFR host different wildlife species and birds (Hofer et al., 2004). The site is rich in tree species of conservation significance including African Blackwood (Dalbergia melanoxylon), Milicia excelsa and Pterocarpus angolensis thickets, and several streams intersect the woodland.

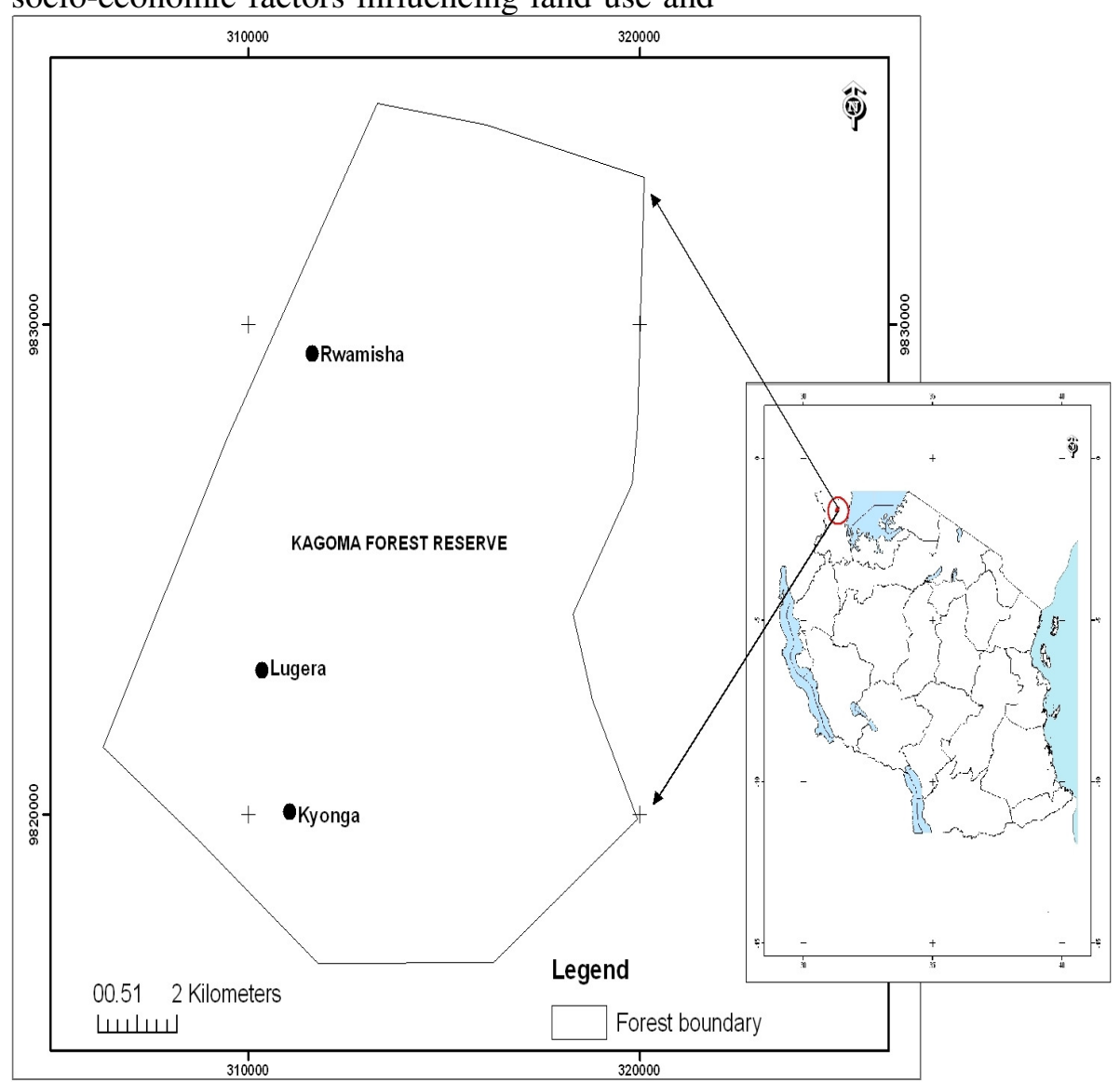

Figure 1 Location of KFR, Tanzania 
Determination Of Socio-Economic Factors Influencing Land Use Change

Data were collected by interviews using questionnaires, focus group discussions and direct observations. Three villages were selected based on accessibility and proximity to KFR. A total of 93 households (45 women and 48 men) in the selected villages were randomly picked for interviews. The questionnaires were addressed to extract information on the expansion of livestock keeping activities, demand of forest resources to the community in and around KFR, farm expansion, price of agricultural products, households' size, land rights, knowledge of land cover change and government restrictions on the use of KFR.

\section{Focus Group Discussions}

In the focus group discussions, government officials and long time residents were involved. A checklist of questions of interest was used to guide the discussions which availed information that could not be picked by using structured questionnaire. Such information included probing questions to capture the historical trends over time with regards to land cover dynamics including vegetation cover change, settlements patterns, farm expansions and grasslands. It also intended to obtain information on institutional arrangements regulating resource use, population dynamics and community awareness about the land use and vegetation cover change. The observation acted as a cross checking mechanism for the extent of settlement and farm expansion towards the forest, pit sawing, charcoal harvest and honey harvesting from KFR.

\section{Analysis of Land Use and Vegetation Cover Changes}

Materials used in the study were Landsat 5 TM of June, 1988, Landsat 7 ETM + imagery of June, 1999 and Landsat 7 ETM + of June, 2010. Topographical maps with scale of 1:50,000 were used for geo-referencing Landsat scenes. Global Positioning System (GPS) was used in land use and cover map verification. The images were selected based on seasonality of the imageries and spatial resolution $(30 \mathrm{~m})$. The land use/cover was captured on the basis of Landsat $5 \mathrm{TM}$ p172r061 scene of August, 1988, Landsat 7 $\mathrm{ETM}+$ p172r061 of 1999 and Landsat7 - ETM + p172r061 of 2010. The imageries were obtained from archive of the Geo-Network Limited, Tanzania. Topographical sheets with scale of 1:50 000 of 1967 were acquired from the Ministry of Lands, Housing and Human
Settlements Development for geo-referencing Landsat images and during the preparation of land use/cover interpretation key.

Data Analysis

Content and structural-functional analysis approaches were used to analyze qualitative information. Kajembe (1994) recommends this technique in explaining the way how social facts relate each other in a social system and the way they relate to the natural physical environment. Logistic regression model was used in analyzing inferential statistics. Inferential statistics provide an idea on whether the patterns explained in the sample population are likely to apply to the population from which the samples were taken (Kajembe, 1994).

\section{Results and Discussion \\ Socio-economic Factors Influencing Land Use and Vegetation Cover Changes}

Table 1 shows a summary of the socioeconomic factors and the nature of their influence on the land use and vegetation cover change. Land use and vegetation cover change which has occurred in this study is influenced by a number of socio-economic factors. The socioeconomic factors which were considered and tested using binary logistic regression model include increase of livestock keeping, education level, population immigration, prices of cash crops, land rights or land tenure, shifting cultivation, demand for forest products and farm increase.

\section{Education Level}

The results show that, there was a negative regression coefficient of education of household head which implied that there was an inverse relationship. This implies that an increase in educated person decreased the odds ratios on land use/vegetation cover change by a factor of 0.341 . It is the fact that an increase in the level of education of the household reduces the possibility of causing environmental degradation. A person is exposed to the knowledge on wise use of resources including agricultural practices because an educated person will tend to practice more environmental friendly agricultural land use. Furthermore, as forest clearing is driven by economic related factors, education tends to improve the economic power of the society thus reducing forest dependence. However, in this study the literacy level of the household was not statistically significant $(\mathrm{p}=$ 0.413 ). This may be due to the fact that $55.9 \%$ of the respondents interviewed had no formal 
education, while $2.2 \%$ had secondary education as shown in Table 2. Kajembe and Luoga (1996) argued that education tends to create awareness, positive attitudes, social values, and motivation which stimulate self reliance.

Table 1 Logistic regression model on socio-economic factors influencing land cover dynamics

\begin{tabular}{|c|c|c|c|c|c|c|c|c|}
\hline \multirow[t]{2}{*}{ Variable } & \multirow[t]{2}{*}{ B } & \multirow[t]{2}{*}{ S.E. } & \multirow[t]{2}{*}{ Wald } & \multirow[t]{2}{*}{ df } & \multirow[t]{2}{*}{ Sig } & \multirow[t]{2}{*}{$\operatorname{Exp}(ß)$} & \multicolumn{2}{|c|}{ 95\% C.I for $\operatorname{Exp}(\beta)$} \\
\hline & & & & & & & Lower & Upper \\
\hline Education & -1.084 & 1.324 & 0.670 & 1 & $0.413 \mathrm{~ns}$ & 0.338 & 0.25 & 4.533 \\
\hline $\begin{array}{l}\text { Livestock } \\
\text { keeping }\end{array}$ & 2.123 & 1.347 & 2.484 & 1 & $0.043 \mathrm{~s}$ & 8.354 & 1.019 & 35.568 \\
\hline $\begin{array}{l}\text { Population } \\
\text { growth }\end{array}$ & 0.992 & 0.623 & 1.415 & 1 & $0.232 \mathrm{~ns}$ & 2.465 & 0.554 & 11.128 \\
\hline $\begin{array}{l}\text { Forestry } \\
\text { products }\end{array}$ & 2.550 & 1.356 & 1.057 & 1 & $0.050 \mathrm{~s}$ & 12.805 & 1.897 & 182.705 \\
\hline $\begin{array}{l}\text { Shifting } \\
\text { cultivation }\end{array}$ & 1.876 & 0.609 & 9.489 & 1 & $0.024 \mathrm{~s}$ & 6.526 & 0.279 & 152.909 \\
\hline $\begin{array}{l}\text { Cash crop } \\
\text { prices }\end{array}$ & 1.962 & 0.474 & 17.133 & 1 & $0.021 \mathrm{~s}$ & 7.112 & 1.394 & 35.132 \\
\hline Farm size & 0.724 & 0.412 & 2.333 & 1 & $0.018 \mathrm{~s}$ & 2.062 & 0.264 & 32.853 \\
\hline Land tenure & 1.620 & 0.848 & 3.649 & 1 & $0.042 \mathrm{~s}$ & 5.052 & 1.132 & 26.087 \\
\hline
\end{tabular}

Model chi-square $=34.756$, Degree of freedom $=8,2$ Log likelihood $=69.58$, Overall percentage $=93 \%$ Number of cases $=93$, $s=$ statistically significant, and $n s=$ statistically not significant at 0.05 level of significance, $\beta=$ Regression coefficients which stand for the odds ratio of probability of success to the probability of failure. S.E. = Standard error of the estimate, Wald statistics $=[\beta / S . E .]^{2}, d f=$ degree of freedom, Sig = significance level, $E x(\beta)=e \beta$ where $e=2.718$.

Table 2: Level of Education of the People in and around KFR

\begin{tabular}{lll}
\hline Response Item & Frequency & Percentage \\
\hline No formal education & 52 & 55.9 \\
Primary Education & 38 & 40.9 \\
Secondary Education & 2 & 2.2 \\
Adult Education & 1 & 1.1 \\
Total & 93 & 100.0 \\
\hline
\end{tabular}

\section{Livestock Keeping}

The odds ratio for land use/vegetation cover change increased by a factor of 8.354 (Table 1). This means that as the number of households keeping livestock in a large number increases in $\mathrm{KFR}$, then search for grazing land will have an impact on the natural forest. The results indicate that livestock keeping had statistically significant $(p=0.043)$ influence on land cover change in KFR. This means that the structure of KFR is to a large extent influenced by the increased amount of cattle. About $93.7 \%$ admitted to be involved in livestock keeping and $84.9 \%$ admitted to keep more than 50 cattle per household. Kaimowitz (1995) reported that cattle husbandry is one of the major factors influencing deforestation. The report revealed that the role of cattle in deforestation varies, depending upon the type of production system.

\section{Population Growth around KFR}

Table 1 shows that population had a positive regression coefficient meaning that an increase in one unit of migrant to the area increased the odds ratio of land use/land cover change by a factor of 2.465. The influence of population growth was statistically insignificant $(\mathrm{p}=0.232)$. Population growth in certain places is normally facilitated by several factors including the availability of land, which provides a room for migrants to establish settlements. It was observed that the community around KFR is mainly occupied by migrants by $96.8 \%$ especially people from neighbouring countries. About $89.2 \%$ of the respondents revealed that the major driver of immigration was the availability of arable land. This observation concur with findings by Mbonile et al. (2003) who reported that major reasons for in-migration is the peoples movement from their former residence to seek land for cultivation and habitation. It was learnt that there was an inflow of people which have added more demand of resources in KFR and consequently more clearance of land for agriculture, livestock keeping, construction of houses and energy. This argument is also supported by Noe (2003) who 
reported that Maasai population increased by $9.5 \%$ due to in-migration population, which caused increased demand of more land for settlement and agriculture between Mountain Kilimanjaro and Amboseli Wildlife corridor and finally led to land use changes in the area.

\section{Demand for Forest Products}

Demand for forest products had positive regression coefficient, meaning that increase of demand of one unit in forest products increased the odds ratio of land use/vegetation cover change by a factor of 12.805 . Forest products in this context include all products (firewood, timber, poles and charcoal), which are used by adjacent local communities. It was observed in this study that local communities in and around KFR are depending on these products, for energy, cash and construction. About $98 \%$ of the respondents admitted to have access to the forest products, where $76 \%$ admitted to clear forest for timber, $85 \%$ cleared for charcoal burning while $56 \%$ cleared for poles, and firewood. This observation of rural community's dependence on these resources is also reported by Mbonile et al. (2003) that, since independence, the government has not yet provided a strategy for providing alternative source of energy for rural communities in Tanzania. The use and demand of forest products were observed during field survey and trees were cut down for charcoal, timber, and energy source in KFR. Its influence on land use and land cover changes was found to be significant $(\mathrm{p}=0.050)$.

\section{Shifting Cultivation}

There was a positive regression coefficient of shifting cultivation (Table 1), which implied that an increase in one unit of household shifting to new farm area increased the odds ratio for land use/vegetation cover change by a factor of 6.526. This means that the numbers of people shifting around in search of land for cultivation had an impact on natural forest and emergence of another land use/cover. The results indicate shifting cultivation had statistically significant influence on land cover change ( $\mathrm{p}=0.024)$. This meant that the structure of KFR was to a large extent influenced by the practice of shifting cultivation. About $87.1 \%$ of respondents admitted to practice shifting cultivation. Shifting cultivation is encouraged by lack of adequate land tenure arrangements encourages self allocation of land without any authority as the land is considered a common property that can be used without control. The influence of shifting cultivation on land use/land cover changes was also reported by Kummer (1992) in upper Philippines that such practices were encouraged by poor land tenure and development standards. These results concur with findings of Opulukwa (2001) who observed that clearance of woodland for cashewnut production is by far the largest destruction of African Black wood. New large areas were observed opened yearly from forestland to agricultural land. The information extracted from the satellite imagery of the study area revealed a sharp decrease of forest land, where about 79.02 ha of the forest has been converted to cultivation and settlement lands during 1988-1999. Also, 112.65 ha of the forested areas were converted to cultivation and settlement lands during 19992010.

\section{Agricultural Crop Prices}

The results in Table 1 indicate that there was a positive regression coefficient of cash crop prices. This was to say that an increase of one unit of cash crop price increased the odds ratio from land use/vegetation cover change by a factor of 7.112. This implied that the increase of cash crop prices motivated households to expand their farms in order to harvest more in the following season or year. The results show that, the influence of price increased on land use/cover changes was statistically significant ( $p$ $=0.021$ ). Attractive cash crop price was one of the factors, which had positive influence on expanding agricultural land because it attracted more number of rural labor forces into agricultural industry. The influence of price on farm expansion was also observed in Kilimanjaro by Noe (2003) due to commercialization and trade liberalization, which caused prices of crops like wheat and maize to rise.

\section{Expansion of Farm Sizes}

There was a positive regression coefficient of expansion of farm size (Table 1), which implied that an increase in one unit of household expanding a farm to a new farm area increased the odds ratio for land use/vegetation cover change by a factor of 2.062. This meant that the numbers of people expanding their farms so as to have larger farms for cultivation had impact on the natural forest and emergence of another land use and cover. The results indicated that, the influence of farm sizes expansion on land use/cover changes was statistically significant ( $p$ $=0.018$ ). Of the total respondents $67.7 \%$ admitted that household's farms were expanding compared to the previous years. Majority of the 
respondents reported to use poor farming methods without application of fertilizers that increase demand for productive lands. Also, 70\% of the farms were located at a distance of less than $1 \mathrm{~km}$ from the forest edge, this implies that, there is interference between these farms and the structure of the forest. Lyaruu (2002) and Tiffen (2003) reported that expansion of farms for cultivation in the world has changed land cover to more agro-ecosystems and less cover of natural vegetation. These changes are fuelled by the growing demand for agricultural products that are important for improving food security and generate income, not only for the rural poor but also for the large-scale investors in commercial farming sector.

\section{Land Tenure}

The results indicated that there was a positive regression coefficient of land tenure insecurity (Table 1), which meant that an increase of one unit of household land tenure insecurity increased the odds ratio for land use/cover change by a factor of 5.052. Land tenure insecurity was statistically significant $(\mathrm{p}=$ 0.042 ). Security of land tenure over land occupied by a household significantly increased the temptation of expanding unplanned farms towards the neighboring forests and woodlands. Usually insecure pieces of land were occupied without title deed or certificate of occupancy. The land which was not demarcated and surveyed was normally not respected by the occupier and is likely to be abandoned and shift to another piece of land in the same neighborhood or anywhere else. This situation might have been the cause of poor land use practices like shifting cultivation and expansion of agricultural farms unnecessarily observed during the field survey in the area. It was revealed that only $8 \%$ of the respondents obtained land through inheritance, while 92\% acquired land through slashing the bushes and cutting the trees to create own farms. This observation concur with Kikula (1997) findings who reported that security of land tenure had a direct link with sustainable farming practices which in turn enable sustainable natural resources management. Land use and related rights play a key role in determining the use and sustainable management of land resources since they specify accessibility of using resources.

Land Use and Vegetation Cover Distribution for Three Time Periods

Analysis of the land cover maps for 1988, 1999 and 2010 (figure 2) showed the variation in vegetation cover between the three time periods under consideration. In year 1988, bushland dominated the area by covering $27.37 \%$ (4570.43 ha) followed by grassland $24.35 \%$ (4065.50 ha), then woodlands $23.12 \%$ (3860.16 ha), settlements $15.46 \%$ (2581.10 ha), forest $9.56 \%(1593.20 \mathrm{ha})$, while cultivated land occupied $0.16 \%$ (27.53 ha).

It was evident that in 1999, woodlands occupied the largest area by $28.92 \%$ (4828.85 ha) due to selective logging of the most preferred timber trees in the closed forest. Bushland occupied 23.5\% (3923.43 ha) followed by grassland which covered $21.64 \%$ (3614.16 ha) of the forest, settlement area $15.98 \%$ (2667.56 ha), then cultivated land $6.07 \%$ (1013.31ha) while forest area covered only 3.9\% (650.61 ha of the total area. During this period woodlands, cultivated land and settlement increased by 968.69 ha $(5.8 \%), 985.78$ ha $(5.9 \%)$ and 86.46 ha $(0.52 \%)$ respectively. The grassland, forest and bushland decreased by 451.34 ha $(2.7 \%)$, 942.59 ha $(5.64 \%)$ and 647 ha $(3.87 \%)$ respectively. 


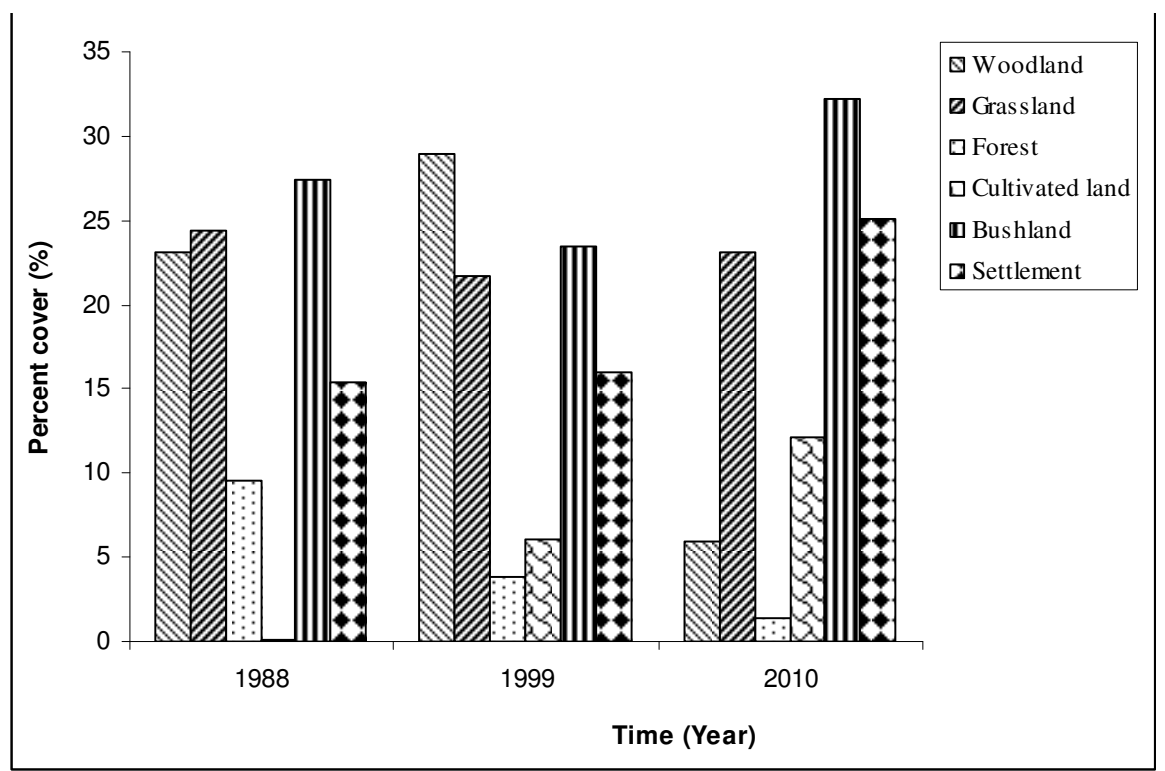

Figure 2 Land Cover Distribution for KFR between 1988 and 2010

In year 2010, bushland increased in terms of coverage from previous $23.5 \%$ (3923.43 ha) to $32.25 \%$ (5385.9 ha) of the total area and continued to take the lead in coverage of the area followed by settlement area $25.11 \%(4193.32$ ha), grassland covered $23.15 \%$ (3865.39 ha), cultivated land $12.14 \%$ (2027.20 ha), followed by woodlands which occupied $5.95 \%$ (993.71 ha), while the forested area covered only $1.39 \%$ (232.4 ha) of the total area. During this period (1999-2010), the results show a substantial decrease in forest cover from $3.9 \%$ (650.61 ha) to $1.39 \%$ (232.4 ha), while the woodlands decreased from $28.92 \%$ (4828.85 ha) to $5.95 \%$ (993.71 ha). The results also show that the grassland, cultivated land, bushland, and settlement increased by $1.5 \%$ ( $251.23 \mathrm{ha}$ ), $6.07 \%$ (1013.89 ha), 8.76\% (1462.47 ha) and 9.14\% (1525.76 ha) respectively. The results clearly indicated that cultivated land and settlement areas increased in both temporal periods. This implies that agricultural activities increased in both periods at the expanse of other land cover types like forests and woodlands. Agricultural expansion is among reported activities, which have significant effect on natural vegetation (Ngalande, 2002; Noe, 2003). The continuous increase in cultivated land is also reflected in an increased area under settlements. Settlements expansion has an implication on increase in population size as a result demand for more resources and area for cultivation.

Table 3 Cover area, changed area and the percentage cover change between 1988 and 1999

\begin{tabular}{|c|c|c|c|c|c|c|}
\hline \multicolumn{3}{|c|}{ Land cover in 1988} & \multicolumn{4}{|c|}{ Land cover in 1999} \\
\hline Cover class & Area (ha) & $\begin{array}{l}\% \\
\text { cover } \\
\end{array}$ & Area (ha) & $\%$ cover & $\begin{array}{l}\text { Area change } \\
\text { (ha) }\end{array}$ & $\begin{array}{l}\% \text { Cover } \\
\text { change }\end{array}$ \\
\hline Woodlands & 3860.16 & 23.12 & 4828.85 & 28.92 & 968.69 & 5.8 \\
\hline Grassland & 4065.5 & 24.35 & 3614.16 & 21.64 & -451.34 & -2.7 \\
\hline $\begin{array}{l}\text { Forest } \\
\text { Cultivated }\end{array}$ & 1593.2 & 9.54 & 650.61 & 3.9 & -942.59 & -5.64 \\
\hline land & 27.53 & 0.16 & 1013.31 & 6.07 & 985.78 & 5.9 \\
\hline Bushland & 4570.43 & 27.37 & 3923.43 & 23.5 & -647 & -3.87 \\
\hline Settlement & 2581.1 & 15.46 & 2667.56 & 15.98 & 86.46 & 0.52 \\
\hline Total area & 16697.92 & 100 & 16697.92 & 100 & & \\
\hline
\end{tabular}


Table 4 Cover area, changed area and the percentage cover change between 1999 and 2010

\begin{tabular}{|c|c|c|c|c|c|c|}
\hline \multicolumn{3}{|c|}{ Land cover in 1999} & \multicolumn{4}{|c|}{ Land cover in 2010} \\
\hline Cover class & Area (ha) & $\begin{array}{l}\% \\
\text { cover }\end{array}$ & Area (ha) & $\begin{array}{l}\% \\
\text { cover }\end{array}$ & $\begin{array}{l}\text { Area change } \\
\text { (ha) }\end{array}$ & $\begin{array}{l}\% \text { Cover } \\
\text { change }\end{array}$ \\
\hline Woodland & 4828.85 & 28.92 & 993.71 & 5.95 & -3835.14 & -22.97 \\
\hline Grassland & 3614.16 & 21.64 & 3865.39 & 23.15 & 251.23 & 1.5 \\
\hline $\begin{array}{l}\text { Forest } \\
\text { Cultivated }\end{array}$ & 650.61 & 3.9 & 232.4 & 1.39 & -418.21 & -2.5 \\
\hline land & 1013.31 & 6.07 & 2027.2 & 12.14 & 1013.89 & 6.07 \\
\hline Bushland & 3923.43 & 23.5 & 5385.9 & 32.25 & 1462.47 & 8.76 \\
\hline Settlement & 2667.56 & 15.98 & 4193.32 & 25.11 & 1525.76 & 9.14 \\
\hline Total area & 16697.92 & 100 & 16697.92 & 100 & & \\
\hline
\end{tabular}

As revealed from Table 3, woodlands and settlement increased at a rate of $88.06 \mathrm{ha} /$ year (0.53\%/year) and 7.86 ha/year (0.05\%/year) respectively over an average period of 11 years (i.e.1988 and 1999) assuming a linear increase. The forest cover decreased consistently at a rate of -85.69 ha/year $(-0.51 \% / y e a r)$ over an average period of 11 years (i.e.1988 and 1999) assuming a linear decrease. It is possible that the decrease in forest and increase in settlement cover is attributed to increased demand for land. This rapid increase might be due to clear felling of trees for firewood, poles, timber, and increased settlement and agricultural activities (banana farms and subsistence farming). This has also been brought out by local people during the interviews and about $85 \%$ of the respondent reported cutting trees. Also, bush fires have been reported to be a serious problem in recent years. It is clear from Table 4 that the forest area decreased consistently over 11 years (i.e. 1988 1999) while cultivation increased at a rate of 89.62 ha/year $(0.54 \% / y e a r)$. Table 2 revealed that grassland, cultivated land, bushland and settlement cover increased between 1999 and 2010. The grassland increased at a rate of 22.84 ha/years $(0.14 \% /$ year $)$, cultivated land increased at a rate of $92.17 \mathrm{ha} /$ year ( $0.55 \% / y e a r)$, bushland increased at a rate of $132.95 \mathrm{ha} /$ year (0.8\%/year) and the settlement cover increased at a rate of 138.71 ha/year $(0.83 \% /$ year $)$ over an average period of 11 year (i.e.1999 and 2010). The expansion of grassland, bushland, settlement and cultivated areas reflects on the land use transformation in and around KFR. The increasing population as a result of refugees' influx and immigrants from other districts in Tanzania has had impact on the forest resources in the study area.

\section{Conclusions}

In this study, socio-economic factors influencing land use and vegetation cover change in and around KFR were investigated.
The observed land cover changes have been influenced mainly by socio-economic factors, which are land tenure, cash crop prices, livestock keeping, demand for forest products, increase of farm sizes and shifting cultivation. Other factors that caused changes in land cover include population growth and level of education. From people's perspective, livestock keeping ranked the first among the socio-economic factors affecting KFR. The results revealed that bushland, grassland, cultivated land and settlement areas have increased in the last 23 years, where by forest land and woodland decreased linearly during the same period. This situation has not only reduced wildlife habitat that is rich in plant species but also may result into forest extinction in future if the situation is left unattended. Environmental education is needed to maintain the existing natural vegetation since human activities have seriously affected the forest resources.

\section{Acknowledgements}

The authors highly acknowledge the financial support from the project 'Q705Vegetation Shift in the Savanna and Miombo Woodlands of North-eastern Tanzania" funded by ESSARP which enabled our fieldwork and other study logistics be accomplished. We also thank the Kagera Region Forest and Beekeeping Division and Natural Resource Advisors for granting a permit to conduct our study in their areas of jurisdiction. Finally, we thank Prof. Boniphace Mbilinyi for providing technical assistance on GIS and Remote sensing issues related to the study.

\section{References}

Bailey, B.K. (1994), Methods of Social Research. The free press Clier-MacMillan Publishers, New York, USA. 813pp.

Dewan, M. A. and Yamaguchi, Y. (2009), Using remote sensing and GIS to detect and monitor 
land use and land cover change in Dhaka Metropolitan on Bangladesh during 1960-2005. Environmental Monitoring and Assessment 150, $237-249$.

Kaihura, F. and Stocking, M. (2003), Agricultural biodiversity in smallholder farms of East Africa. New York: United Nations University Press.

Kajembe, G. C., (1994), Indigenous Management system as a basis for community forestry in Tanzania: A case study for Dodoma Urban and Lushoto Districts. Tropical Resource Management Paper No.6, Wageningen Agricultural University, Wageningen. 194pp.

Kajembe, G.C., and Luoga, E.J. (1996), Socioeconomic Aspects of Tree Farming in Njombe District. Consultancy Report to the Natural Resources Conservation and Land use Management Project (HIMA-Njombe), funded by DANIDA, FORCONSULT, Morogoro. 98pp. Kikula, I. S. (1997), Policy Implication on Environment. The Case of Villagisation in Tanzania. DUP (1996) LTD, Dar es Salaam. $327 \mathrm{pp}$.

Lambin, E. F., Geist, H. J. and Lepers, E. (2003), Dynamics of land use and land cover change in tropical regions. Annual Review of Environment and Resources 28, $206-241$.

Lyaruu, H. V. (2002), Plant Biodiversity Component of the Land Use Change, Impacts and Dynamics Project, Mt. Kilimanjaro, Tanzania. 43pp.

Mbonile, J. M., Misana, B. S. and Sokoni, C. (2003), Land use Change and Root Causes on the Southern Slopes of Mount Kilimanjaro, Tanzania. LUCID Project Working Paper no. 25, Nairobi, Kenya, International Livestock Research institute [http://www.lucidafrica.org] Site visited on 12/03/2010.

Misana, S. B., Majule, A.E. and Lyaruu, H. V. (2003). Linkages between Changes in Land Use, Biodiversity and Land Degradation on the Slopes of Mount Kilimanjaro, Tanzania. LUCID Working paper No. 38. International Livestock Research Institute. Nairobi. 24pp.

Mugisha, S. (2002) Root causes of land cover/use change in Uganda: An account of the past 100 years. LUCID Working paper No.14. International Livestock Resources Institute. Nairobi. 18pp.

Munishi, P. K. T., Shear, T. H. and Temu, R. P. C. (2006), Household level impacts on forest resources and the feasibility of using market based incentives for sustainable management of the forest resources of the Eastern Arc
Mountains of Tanzania In: Proceeding of Africa Mountains High Summit Conference, 6 - 10 May 2002, U.N. Offices, Nairobi, Kenya. 12pp.

Ngalande, H. (2002), Spatial Environmental Assessment of the impact of Land use on Land Resources in Lusitu Area, Siabonga District, Zambia. Dissertation for Award of MSc Degree at Sokoine University of Agriculture, Morogoro, Tanzania, 94pp.

Noe, C. (2003), The Dynamic of Land use Changes and their Impacts on the Wildlife Corridor Between Mount Kilimanjaro and Amboseli National Park, Tanzania LUCID Report No.31 International Livestock Research institute, Nairobi, Kenya. [http://www.lucidafrica.org] site visited on 12/03/2013.

Olson, J. M., Misana, S., Campbell, D. J., Mbonile, M. and Mugisha, S. (2004), The Spatial Patterns and Roots Causes of Land use Changes in East Africa. LUCID Project Working paper No. 47. Nairobi Kenya International Livestock Research Institute. [http://www.lucidafrica.Org] site visited on 12/02/2013.

Opulukwa, M. J. (2001), Utilization of Dalbergia melanoylon in Tanzania: A case study of Nachingwea District. Dissertation for Award of MSc. Degree at Sokoine University of Agriculture, Morogoro, Tanzania, 102pp.

Richards, J. F. (1990), Land transformation In: The Earth as transformed by human action. Cambridge University Press, New York. pp. 163 -178 .

Strategic plan for the climate change Science Programme. (2003), Land use and Land cover change.

[http://www.climatescience.Gov/Strategicplan20 03/-chap6.html] site visited on 10/3/2013.

Tiffen, M. (2003), Transition in Sub-Saharan Africa: Agriculture, Urbanization and Income growth. World Development 31, 1343 - 1366.

Turner, B.L. Meyer, W.B., and Skole, D.L. (1994), Global land use/land cover change: Towards an integrated program of study. Ambio 23(1), 91-95.

Vanacker, V. (2002), Geormophic Response to Human- Induced Environmental Change in Tropical Mountains Areas. The Austo Ecuatoriano as a case Study. Doctoral thesis, Katholic University of Leuven. pp. 111-119.

Worden, J., Reid, R. And Gichohi, H. (2003), Landuse impacts on large wildlife and livestock in the swamps of the Greater Amboseli Ecosystem Kenya. LUCID Working paper series no. 27. Nairobi Kenya: International Livestock Research Institute. 